\title{
TRF Test in Patients with Hypothalamic-Pituitary Disorders
}

\author{
MaKoto OTSUKI, Makoto TATEIWA AND Shigeaki BABA \\ The Second Department of Internal Medicine, \\ Kobe University School of Medicine, Kobe
}

\begin{abstract}
Synopsis
TRF test with $50-100 \mu \mathrm{g}$ of synthetic TRF was performed in 57 patients with hypothalamic-pituitary disorders. According to the degree and the pattern of TSH response, they were classified as an absent, subnormal, normal or supernormal response and/or delayed pattern of TSH response. 9 of 21 patients with pituitary chromophobe adenoma showed an absent or a subnormal response. Six of them were hypothyroid. 21 of 23 patients with hypothalamic lesions had normal or supernormal TSH response. 5 with a normal response and all of the six with a supernormal response showed clinical or biochemical evidence of hypothyroidism. Since the pituitary of these cases remained intact from tumor invasion, they should be postulated as hypothalamic hypothyroidism. A delayed pattern of TSH response to TRF, where the peak TSH response occurred after $20 \mathrm{~min}$, was observed in 17 of 23 in hypothalamic lesions. 6 of 7 patients with diabetes insipidus showed just the same pattern of TSH response as observed in the patients with determined hypothalamic lesions. This delayed pattern of response and normal or supernormal response to a small dose of TRF, such as 50-100 $\mu \mathrm{g}$, could be used to distinguish hypothalamic lesions from pituitary diseases.
\end{abstract}

Administration of synthetic TRF has been recently introduced as a test of hypothalamic pituitary thyroid function (Bowers et al., 1970; Burgus et al., 1969; Folkers et al., 1969; Hall et al., 1970, 1972; Hershman et al., 1970; Fleisher et al., 1970; Karberg et al., 1971; Otsuki, 1971; Otsuki et al., 1972, 1973a, b; Saito et al., 1971; Sakoda et al., 1970). In normal euthyroid subjects, intravenous administration of synthetic TRF causes a consistent rise of plasma TSH levels. We reported on the standardization of TRF test and the normal range of TSH response to a standard intravenous dose of TRF and its application to the diagnosis of hypothalamic pituitary disorders (Otsuki, 1971; Otsuki et al., 1973a, b). There are only several reports on the TSH response to TRF in small groups of

Received for publication February 28, 1973. patients with hypothalamic pituitary disorders This paper describes the usefulness of the TRF test in a large group of patients with hypothalamic pituitary disorders.

\section{Materials and Methods}

\section{1) Thyrotropin Releasing Factor (TRF)}

Thyrotropin releasing factor used in this study was synthesized following the method of Gillessen et al. (1970) with a slight modification. It was presented as pyroglutamyl-histidyl-proline amide in the form of acetate salt.

\section{2) TRF Test}

Almost all the subjects were fasted overnight and remained sitted throughout the TRF test which was performed early in the morning. Venous blood was withdrawn at zero time for the estimation of TSH and routine thyroid function tests, and 50 or $100 \mu \mathrm{g}$ of TRF was rapidly administered intravenously through the same needle. Blood samples were subsequently 
obtained for TSH estimation at 10, 20, 30, and $60 \mathrm{~min}$.

\section{3) Plasma TSH and Other Hormone Assays}

Plasma TSH concentrations were measured by a double antibody radioimmunoassay. A highly purified human TSH and anti-human TSH serum provided from National Pituitary Agency and Human Thyrotropin Research Standard A from National Institute for Medical Research were used. The minimum detectable level of TSH was approximately $0.7-1.7$ $\mu \mathrm{U} / \mathrm{ml}$ in our laboratory.

Routine thyroid function tests included the serum protein bound iodine (PBI; Auto Analyzer methods), the total serum thyroxine level (Tetrasorb test; Dinabot R. I. Lab. Ltd.), the $\mathrm{T}_{3}$ resin sponge uptake (Triosorb test; Dinabot R. I. Ltd.), the thyroidal uptake of ${ }^{131} \mathrm{I}$ at $24 \mathrm{hr}$ and basal metabolic rate.

Plasma HGH was measured by radioimmunoassay using the double antibody technique after Schalch and Parker (1964), serum cortisol by a fluorometric modification accoding to DeMoor et al. (1960).

\section{4) Clinical Subjects}

Twenty-two males and 22 females between sixteen and $37 \mathrm{yr}$ of age agreed to act as controls. To determine the effect of age, 50 and $400 \mu \mathrm{g}$ of TRF were also given to 12 males and 8 females over $70 \mathrm{yr}$ of age. The volunteers were euthyroid with normal circulating levels of thyroid hormone. Subsequent volunteers were informed of the purpose of this study and of the experiences of thoe who had previously received synthetic TRF. After obtaining consent, the TRF test was performed. Fifty-seven patients with hypothalamic pituitary disorders were given TRF in doses of $50-100 \mu \mathrm{g}$. These patients were divided into 4 groups as shown in Table 1.

\section{Results}

\section{1) Control Subjects}

Seven doses of TRF $(25,50,100,200,400$, 800 and $1000 \mu \mathrm{g}$ ) were administered to 44 euthyroid volunteers. The mean maximum TSH increases were linearly related to the log of the dose of TRF between $50-400 \mu \mathrm{g}$ (Otsuki et al., 1972; 1973a, b). To determine the effect of age, 50 and $400 \mu \mathrm{g}$ of TRF were administered to 20 subjects ranging from 70 to $88 \mathrm{yr}$ old. The response to $50 \mu \mathrm{g}$ of TRF in the aged subjects was similar to that in the young, while the response of $400 \mu \mathrm{g}$ of TRF in the aged was smaller than those in the young (Table 2).

We used 50 or $100 \mu \mathrm{g}$ of TRF as a test dose for pituitary TSH reserve according to the results reported previously (Otsuki, 1971; Otsuki et al., 1972, 1973a, b). In normal subjects a detectable rise of plasma TSH was observed within $5 \mathrm{~min}$ and a further rise followed over the next $15 \mathrm{~min}$. Peak level occurred at 10 to $20 \mathrm{~min}$ after $50-100 \mu \mathrm{g}$ of TRF.

Table 1. Patients with hypothalamic-pituitary disorders

\begin{tabular}{|c|c|}
\hline & Number of patients \\
\hline \multicolumn{2}{|l|}{ Group 1.} \\
\hline Pituitary chromophobo adenoma* & 21 \\
\hline \multicolumn{2}{|l|}{ Group 2.} \\
\hline Acromegaly & 6 \\
\hline \multicolumn{2}{|l|}{ Group 3.} \\
\hline Lesions of the hypothalamus & 23 \\
\hline Craniopharyngioma* & 15 \\
\hline Pinealoma & 5 \\
\hline Meningioma of the region of the optic chiasma* & 2 \\
\hline Tumor of the floor of the third ventricle & 1 \\
\hline \multicolumn{2}{|l|}{ Group 4.} \\
\hline Diabetes insipidus** & 7 \\
\hline Total & 57 \\
\hline
\end{tabular}

* Diagnosis was ascertained by operation.

** Clinically diagnosed as diabetes insipidus except nephrogenic diabetes insipidus. 
Table 2. Plasma TSH response of TRF in normal subjects

\begin{tabular}{|c|c|c|c|c|c|c|c|c|c|c|c|}
\hline \multirow{2}{*}{$\begin{array}{l}\text { Dose of } \\
\text { TRF }\end{array}$} & \multirow{2}{*}{\multicolumn{2}{|c|}{$\begin{array}{l}\text { Number } \\
\text { of subjects }\end{array}$}} & \multirow{2}{*}{$\begin{array}{l}\text { Age } \\
\text { (yr) }\end{array}$} & \multicolumn{7}{|c|}{ Time after TRF injection (min) } & \multirow{2}{*}{$\begin{array}{l}\text { Maxi- } \\
\text { mum } \\
\Delta \mathrm{TSH}\end{array}$} \\
\hline & & & & 0 & 10 & 20 & 30 & 60 & 90 & 120 & \\
\hline $25 \mu \mathrm{g}$ & $\begin{array}{c}4 \mathrm{M} . \\
\mathrm{F} .\end{array}$ & $\begin{array}{l}2 \\
2\end{array}$ & $22-30$ & $<1.7^{*}$ & $\begin{array}{l}4.2 \\
\pm 1.2\end{array}$ & $\begin{array}{l}3.8 \\
\pm 1.5\end{array}$ & $\begin{array}{l}3.5 \\
\pm 1.7\end{array}$ & $\begin{array}{l}2.1 \\
\pm 0.4\end{array}$ & 1.7 & 1.7 & $\begin{array}{l}8.8 \\
\pm 1.9\end{array}$ \\
\hline $50 \mu \mathrm{g}$ & $\begin{array}{c}10 \mathrm{M} . \\
\mathrm{F} .\end{array}$ & $\begin{array}{l}5 \\
5\end{array}$ & $22-37$ & $<1.7 \underset{3.6^{*}}{-}$ & $\begin{array}{l}6.9 \\
\pm 0.8\end{array}$ & $\begin{array}{l}8.0 \\
\pm 0.8\end{array}$ & $\begin{array}{l}6.7 \\
\pm 0.5\end{array}$ & $\begin{array}{l}4.4 \\
\pm 0.4\end{array}$ & $\begin{array}{l}3.2 \\
\pm 0.3\end{array}$ & $\begin{array}{l}3.0 \\
\pm 0.5\end{array}$ & $\begin{array}{l}7.9 \\
\pm 0.9\end{array}$ \\
\hline $50 \mu \mathrm{g}$ & $\begin{array}{c}10 \mathrm{M} . \\
\mathrm{F} .\end{array}$ & $\begin{array}{l}5 \\
5\end{array}$ & $71-88$ & $<1.7-\overline{2}^{*}$ & $\begin{array}{l}5.7 \\
\pm 1.2\end{array}$ & $\begin{array}{l}8.0 \\
\pm 1.7\end{array}$ & $\begin{array}{l}7.1 \\
\pm 0.8\end{array}$ & $\begin{array}{l}5.4 \\
\pm 0.8\end{array}$ & & & $\begin{array}{l}7.0 \\
\pm 0.8\end{array}$ \\
\hline $100 \mu \mathrm{g}$ & $\begin{array}{c}10 \mathrm{M} . \\
\mathrm{F} .\end{array}$ & $\begin{array}{l}5 \\
5\end{array}$ & $18-28$ & $<\frac{1.7-}{2.6^{*}}$ & $\begin{array}{l}10.7 \\
\pm 1.7\end{array}$ & $\begin{array}{l}13.1 \\
\pm 1.7\end{array}$ & $\begin{array}{l}12.2 \\
\pm 1.4\end{array}$ & $\begin{array}{l}8.6 \\
\pm 1.7\end{array}$ & $\begin{array}{l}3.3 \\
\pm 0.5\end{array}$ & $\begin{array}{l}2.2 \\
\pm 0.7\end{array}$ & $\begin{array}{l}13.0 \\
\pm 1.7\end{array}$ \\
\hline $200 \mu \mathrm{g}$ & $\begin{array}{c}6 \mathrm{M} . \\
\mathrm{F} .\end{array}$ & $\begin{array}{l}3 \\
3\end{array}$ & $16-38$ & $<\frac{1.7-3^{*}}{2.3}$ & $\begin{array}{l}14.4 \\
\pm 3.4\end{array}$ & $\begin{array}{l}16.1 \\
\pm 2.9\end{array}$ & $\begin{array}{l}17.1 \\
\pm 3.3\end{array}$ & $\begin{array}{l}11.3 \\
\pm 3.8\end{array}$ & $\begin{array}{l}6.3 \\
\pm 2.3\end{array}$ & $\begin{array}{l}4.5 \\
\pm 3.8\end{array}$ & $\begin{array}{l}17.8 \\
\pm 2.3\end{array}$ \\
\hline $400 \mu \mathrm{g}$ & $\begin{array}{c}5 \mathrm{M} . \\
\quad \mathrm{F} .\end{array}$ & $\begin{array}{l}2 \\
3\end{array}$ & 19-34 & $<1.7-6^{*}$ & $\begin{array}{l}14.8 \\
\pm 3.1\end{array}$ & $\begin{array}{l}22.0 \\
\pm 5.3\end{array}$ & $\begin{array}{l}23.8 \\
\pm 6.1\end{array}$ & $\begin{array}{l}12.7 \\
\pm 4.5\end{array}$ & $\begin{array}{l}9.0 \\
\pm 4.3\end{array}$ & $\begin{array}{l}7.7 \\
\pm 3.4\end{array}$ & $\begin{array}{l}22.9 \\
\pm 5.3\end{array}$ \\
\hline $400 \mu \mathrm{g}$ & $\begin{array}{rl}10 & \mathrm{M} \\
\mathrm{F}\end{array}$ & $\begin{array}{l}5 \\
5\end{array}$ & $70-80$ & $<1.7 \overline{5.3}^{*}$ & $14.8 \pm$ & $2.5^{* *}$ & $\begin{array}{l}18.5 \\
\pm 3.2\end{array}$ & $\begin{array}{l}12.8 \\
\pm 3.0\end{array}$ & & & $\begin{array}{l}15.1 \\
\pm 2.8\end{array}$ \\
\hline $800 \mu \mathrm{g}$ & $\begin{array}{l}6 \mathrm{M} . \\
\mathrm{F} .\end{array}$ & $\begin{array}{l}3 \\
3\end{array}$ & $19-28$ & 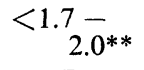 & $\begin{array}{l}11.1 \\
\pm 3.5\end{array}$ & $\begin{array}{l}20.6 \\
\pm 4.2\end{array}$ & $\begin{array}{l}22.8 \\
\pm 4.0\end{array}$ & $\begin{array}{l}13.6 \\
\pm 1.3\end{array}$ & $\begin{array}{l}9.8 \\
\pm 1.4\end{array}$ & $\begin{array}{l}7.3 \\
\pm 2.4\end{array}$ & $\begin{array}{l}23.1 \\
\pm 2.7\end{array}$ \\
\hline $1000 \mu \mathrm{g} * * *$ & $\begin{array}{l}3 \mathrm{M} . \\
\mathrm{F} .\end{array}$ & $\begin{array}{l}2 \\
1\end{array}$ & $24-29$ & $\begin{array}{r}<1.7-\sigma^{*} \\
\end{array}$ & 13.0 & 19.0 & 20.1 & 18.8 & 14.5 & 10.3 & \\
\hline
\end{tabular}

TSH values in $\mu \mathrm{U} / \mathrm{m} l$ (mean \pm SE). The minimum detectable value is $1.7 \mu \mathrm{U} / \mathrm{m} l$.

* Basal values of plasma TSH are represented as the ranges in euthyroid subjects receiving TRF.

** 15 min after TRF injection.

$* * *$ The plasma TSH values are represented as the mean.

The maximum value of $\triangle \mathrm{TSH}$ response of $50 \mu \mathrm{g}$ TRF was not different between males and females: the maximum levels of $\Delta \mathrm{TSH}$ were between 4.2 and $10.8 \mu \mathrm{U} / \mathrm{m} l$ in males and 4.3 and $9.3 \mu \mathrm{U} / \mathrm{m} l$ in females. However, females showed a greater maximum $\Delta \mathrm{TSH}$ increases than males to $100 \mu \mathrm{g}$ of TRF: the maximum value of $\Delta \mathrm{TSH}$ in males was between 4.9 and $9.5 \mu \mathrm{U} / \mathrm{m} l$, while in females 8.7-21.4 $\mu \mathrm{U} / \mathrm{m} l$.

Table 3. Definition of response interms of $\mathbf{w}$ TSH.

\begin{tabular}{lcc}
\hline \multicolumn{2}{c}{ Dose of TRF } \\
\hline & $50 \mu \mathrm{g}$ & $100 \mu \mathrm{g}^{*}$ \\
\hline Absent & $<2.0$ & $<2.0$ \\
Subnormal & $2.0-4.0$ & $2.0-4.0$ \\
Normal & $4.0-11.0$ & $4.0-22.0$ \\
Supernormal & $>11.0$ & $>22.0$ \\
\hline
\end{tabular}

TSH values $(\mu \mathrm{U} / \mathrm{m} l)$ were represented as the increments above basal level.

* Although the maximum $\triangle \mathrm{TSH}$ increases were different between males and females, the same criteria were employed because of the small number of the control subjects.

\section{2) Definition of Response}

On the basis of these results in the control subjects, the responses of plasma TSH in the TRF test were arbitrarily defined as shown in Table 3: (i) absent, (ii) subnormal, (iii) normal and (iv) supernormal.

As mentioned above, in all normal subjects the peak TSH level occurred at 10 to $20 \mathrm{~min}$, cases of which the peak TSH values were obtained later than $20 \mathrm{~min}$ were defined as a delayed response.

\section{3) Patients}

The results of the TRF test were summarised in Table 4.

Group 1. (21 patients with pituitary chromophobe adenoma)

12 patients responded normally and 4 showed a subnormal response, one of whom had clinical and biochemical evidence of hypothyroidism. There were 5 with an absent response, all of whom were hypothyroid. 5 patients with a normal response and 3 with a subnormal response showed a delayed rise 
Table 4. TSH response to TRF test

\begin{tabular}{|c|c|c|c|c|}
\hline & Absent & $\begin{array}{c}\text { Sub- } \\
\text { normal }\end{array}$ & Normal & $\begin{array}{l}\text { Super- } \\
\text { normal }\end{array}$ \\
\hline \multicolumn{5}{|l|}{ Group 1} \\
\hline \multicolumn{5}{|l|}{$\begin{array}{l}\text { Pituitary } \\
\text { chromophobe } \\
\text { adenoma }\end{array}$} \\
\hline Treated ${ }^{*}$ & $5(0)$ & $4(3)$ & $8(40)$ & \\
\hline Untreated & 0 & 0 & $3(1)$ & \\
\hline \multicolumn{5}{|l|}{ Group 2} \\
\hline Acromegaly & 0 & $1(1)$ & $5(4)$ & \\
\hline \multicolumn{5}{|l|}{ Group 3} \\
\hline \multicolumn{5}{|l|}{$\begin{array}{l}\text { Lesions of the } \\
\text { hypothalamus }\end{array}$} \\
\hline Treated** & $2(0) \#$ & 0 & $10(8)$ & $4(4)$ \\
\hline Untreated & 0 & 0 & $5(3)$ & $2(2)$ \\
\hline \multicolumn{5}{|l|}{ Group 4} \\
\hline $\begin{array}{l}\text { Diabetes } \\
\text { insipidus }\end{array}$ & 0 & $1(0)$ & $2(2)$ & $4(4)$ \\
\hline \multicolumn{5}{|c|}{$\begin{array}{l}\text { The number of delayed responses in each group is } \\
\text { shown in parentheses. } \\
\text { * They underwent an operation of craniotomy. } \\
\text { ** } 13 \text { with craniopharyngioma, } 3 \text { with pinealoma } \\
\text { and each one with meningioma of the region } \\
\text { of optic chiasma and tumor of the floor of the } \\
\text { third ventricle underwent an operation of } \\
\text { craniotomy. }\end{array}$} \\
\hline \multicolumn{5}{|c|}{$\begin{array}{l}\text { \# These two patients had a long history, more than } \\
10 \text { years, and underwent an operation of } \\
\text { intradural craniotomy twice and were irradiated } \\
\text { with the telecobalt. }\end{array}$} \\
\hline
\end{tabular}

of TSH.

Group 2. (6 patients with untreated acromegaly)

One had a subnormal TSH response and the other 5 responded normally, one of whom was hypothyroid. 5 of 6 acromegalic patients showed a delayed TSH response.

Group 3. (23 patients with hypothalamic lesions)

Of the 15 craniopharyngioma 11 responded normally, 2 had a supernormal response and 2 showed an absent response. As these 2 patients who showed thyroid hypofunction and an absent TSH response to TRF had a long history, more than 10 years, of this desease and had twice undergone an operation of intradural craniotomy and was irradiated with use of the telecobalt, it was supposed that not only hypothalamus but also pituitary was destroyed in these patients. Of the other 8 with hypothalamic lesions, 4 responded normally and 4 showed a supernormal response of $50 \mu \mathrm{g}$ TRF. All of the six patients with a supernormal response were hypothyroid, however, they showed a normal response to exogenous TSH (Thytropar; Armour, Ltd.) (Table 5).

Table 5. Hypothalamic-pituitary thyroid function

\begin{tabular}{|c|c|c|c|c|c|c|c|c|}
\hline \multirow{2}{*}{ Name } & \multirow{2}{*}{$\begin{array}{l}\text { Age } \\
\text { (yrs) }\end{array}$} & \multirow{2}{*}{ Sex } & \multirow{2}{*}{ Clinical Diagnosis } & \multicolumn{5}{|c|}{$\mathrm{TSH}(\mu \mathrm{U} / \mathrm{ml})$ response to TRF } \\
\hline & & & & 0. & $10^{\prime}\left(15^{\prime}\right)$ & $20^{\prime}$ & $30^{\prime}$ & $60^{\prime}$ \\
\hline K. Y. & 6 & M. & Craniopharyngioma** & 1.7 & - & - & 29.6 & - \\
\hline I. N.+ & 37 & M. & Craniopharyngioma** & 1.7 & 22.8 & 20.1 & 25.1 & 23.1 \\
\hline K. K. & 26 & M. & Pinealoma** & 1.7 & \multicolumn{2}{|l|}{18.5} & 18.5 & 12.5 \\
\hline K. H. & 16 & M. & Pinealoma*** & 2.3 & 13.2 & 23.7 & 28.1 & 23.1 \\
\hline K. O. & 50 & $\mathrm{~F}$ & Meningioma of optic chiasma** & 1.7 & 12.8 & 14.2 & 22.2 & 15.2 \\
\hline T. T. & 36 & F. & $\begin{array}{l}\text { Tumor of the floor of } \\
\text { the third ventricle*** }\end{array}$ & 3.6 & 34.7 & & 52.8 & 27.4 \\
\hline
\end{tabular}

The TRF dose was $50 \mu \mathrm{g}$ iv single injection in all cases except one $\left(t^{-}\right)$who received $100 \mu \mathrm{g}$.

* 10 USP of bovine TSH (Thytropar; Armour, Ltd.) was injected im.

** Diagnosis was ascertained by operation. 
Group 4. (7 patients with clinical evidence of diabetes insipidus)

One responded subnormally, 2 showed a normal response and 4 showed a supernormal response. Each one with subnormal and normal response had biochemical evidence of hypothyroidism. 4 with a supernormal response were euthyroid. In 6 of 7 delayed TSH responses were observed.

\section{Discussion}

The mechanism of the action of TRF on the pituitary gland was poorly understood. TRF appeared to stimulate not only the release of preformed TSH but also the biosynthesis of new TSH (Bowers et al., 1967; Mittler et al., 1969; Wilber, 1971). Bowers et al. (1967) reported that a small amount of TRF depleted the stores of pituitary $\mathrm{TSH}$, while a larger amount of TRF did not change the pituitary TSH contents and concluded that only a larger amount of TRF could stimulate both TSH synthesis and release. From these observations, it may be impossible that the newly synthesized TSH is released within $60 \mathrm{~min}$
(Bowers et al., 1967; Wilber, 1971) after these small doses of TRF, such as 50 or $100 \mu \mathrm{g}$. So that the magnitude of the changes in plasma TSH levels after iv administration of $50-100 \mu \mathrm{g}$ of synthetic TRF seems to reflect the reserve pituitary TSH contents. A log-linear dose related response was found within the range of 50 to $400 \mu \mathrm{g}$ of TRF given as a single iv injection (Otsuki et al., 1972, 1973a, b). However, there was a wide individual variation in TSH response to TRF, especially to a large dose of TRF, as shown in Table 2. TSH responses of $400 \mu \mathrm{g}$ TRF in aged euthyroid subjects showed wider individual variations than in young subjects. As a whole, they had a reduced TSH response of $400 \mu \mathrm{g}$ TRF. However, the responses of $50 \mu \mathrm{g}$ TRF were just similar to those in the young. In utilizing TRF for pituitary TSH reserve test, we employed a relatively small dose of TRF such as 50-100 $\mu \mathrm{g}$ (Otsuki, 1971; Otsuki et al., $1972,1973 \mathrm{a}, \mathrm{b})$. As the peak level occurred at 10 to $20 \mathrm{~min}$ after $50-100 \mu \mathrm{g}$ of TRF in all control subjects, we arbitrarily defined as a delayed type of TSH response when the peak response was observed at $30 \mathrm{~min}$ or after. This definition must be limited only when a

in patients with supernormal TSH response

\begin{tabular}{|c|c|c|c|c|c|c|c|c|c|c|}
\hline \multirow{2}{*}{$\begin{array}{l}\text { BMRR } \\
(\%)\end{array}$} & \multirow{2}{*}{$\underset{(\mu \mathrm{g} / \mathrm{d} l)}{\mathrm{PBI}}$} & \multirow{2}{*}{$\begin{array}{c}\mathrm{T}_{3} \mathrm{RSU} \\
(\%) \\
\mathrm{o} / \mathrm{u}\end{array}$} & \multicolumn{4}{|c|}{ TSH test* } & \multicolumn{4}{|c|}{ Insulin Hypoglycemia } \\
\hline & & & & 0. & $24^{\circ}$ & $48^{\circ}$ & & 0. & $30^{\prime}$ & $60^{\prime}$ \\
\hline-36 & 3.8 & 24.0 & & & & & $\begin{array}{l}\text { B. G.: } \\
\text { HGH: }\end{array}$ & $\begin{array}{l}57 \\
12.8\end{array}$ & $\begin{array}{c}28 \\
5.2\end{array}$ & $\begin{array}{c}52 \\
2.4\end{array}$ \\
\hline-36 & 3.1 & 25.1 & $\mathrm{~T}_{4}:$ & 3.4 & 6.4 & 5.5 & $\begin{array}{l}\text { B. G.: } \\
\text { HGH: }\end{array}$ & $\begin{array}{l}57 \\
2.7\end{array}$ & $\begin{array}{c}10 \\
1.2\end{array}$ & $\begin{array}{l}16 \\
1.1\end{array}$ \\
\hline-25 & 1.8 & 22.6 & $\begin{array}{l}\text { PBI: } \\
\mathrm{T}_{4}:\end{array}$ & $\begin{array}{l}1.8 \\
1.4\end{array}$ & $\begin{array}{l}2.0 \\
1.7\end{array}$ & $\begin{array}{l}2.2 \\
2.8\end{array}$ & $\begin{array}{l}\text { B. G.: } \\
\text { HGH: } \\
\text { C.S.: }\end{array}$ & $\begin{array}{c}84 \\
0.6 \\
2.2\end{array}$ & $\begin{array}{c}32 \\
0.5 \\
5.6\end{array}$ & $\begin{array}{l}75 \\
0.7 \\
5.6\end{array}$ \\
\hline-20 & 2.6 & 20.4 & $\begin{array}{l}\text { PBI: } \\
\mathrm{T}_{4}:\end{array}$ & $\begin{array}{l}2.6 \\
4.0\end{array}$ & $\begin{array}{l}5.5 \\
8.5\end{array}$ & $\begin{array}{r}7.8 \\
11.9\end{array}$ & $\begin{array}{l}\text { B. G.: } \\
\text { HGH: }\end{array}$ & $\begin{array}{c}60 \\
6.1\end{array}$ & 26 & $\begin{array}{l}34 \\
7.0\end{array}$ \\
\hline-22 & 4.4 & 22.2 & $\begin{array}{l}\text { PBI: } \\
\mathrm{T}_{4}:\end{array}$ & $\begin{array}{l}4.4 \\
6.4\end{array}$ & $\begin{array}{r}8.2 \\
12.1\end{array}$ & $\begin{array}{r}8.8 \\
13.7\end{array}$ & $\begin{array}{l}\text { B. G.: } \\
\text { HGH: } \\
\text { C. S.: }\end{array}$ & $\begin{array}{c}96 \\
1.1 \\
14.0\end{array}$ & $\begin{array}{c}42 \\
1.0 \\
12.0\end{array}$ & $\begin{array}{l}70 \\
6.0 \\
35.0\end{array}$ \\
\hline-21 & $4.5\left(\mathrm{~T}_{4}\right)$ & 25.3 & $\mathrm{~T}_{4}:$ & 4.5 & 5.7 & 5.7 & $\begin{array}{l}\text { B. G.: } \\
\text { HGH: }\end{array}$ & $\begin{array}{l}96 \\
5.2\end{array}$ & $\begin{array}{l}44 \\
3.8\end{array}$ & $\begin{array}{l}82 \\
5.1\end{array}$ \\
\hline
\end{tabular}

*** Diagnosis was confirmed by PVG.

\# B. G. represents blood glucose level $(\mathrm{mg} / \mathrm{d} l)$, $\mathrm{HGH}$ represents plasma growth hormone level $(\mathrm{m} \mu \mathrm{g} / \mathrm{m} l)$, C. S. represents plasma cortisol level $(\mu \mathrm{g} / \mathrm{d} l)$. 
small amount of TRF (100 $\mu \mathrm{g}$ or less) was used, because, as shown in Table 2, a prolonged period was required for the maximum TSH response when larger doses of TRF (200 $\mu \mathrm{g}$ or more) were administered.

The delayed rise in plasma TSH levels observed in the majority of patients with hypothalamic lesions may be a consequence of the abnormality of the cell membrane of the thyrotroph cells; a decrease of the sensitivity to TRF due to long-standing deficiency of the endogenous TRF, or the existence of too many free receptor sites to TRF because of lack of endogenous TRF, or a reduction of the effective receptor sites to TRF (Grant et al., 1972; Wilber \& Seibel, 1972). Recent studies in rats revealed that hypothalamic lesions resulted in decreases in serum thyroxine, PBI and TSH levels, but that the thyrotroph cells did not atrophy nor did the TSH concentration in the pituitary gland decrease (D'Angelo, 1958; Martin et al., 1970). These animals with hypothalamic lesions responded to goitrogen administration (D'Angelo 1958) or to thyroidectomy (Martin et al., 1970) with a definite but blunted rise in serum TSH. This indicates some autonomy or regulation of thyrotroph function by factors other than TRF and suggests that these cells do not atrophy because of loss of hypothalamic stimulation. From these observations, it seems to be quite natural that the patients with hypothalamic lesions responded to a small dose of TRF which acts on the anterior pituitary gland directly. On the other hand, in the patients with pituitary disorders, TSH responses to TRF may be reduced or absent due to loss of thyrotroph cells. However, some patients with an incomplete defect of pituitary thyrotrophs could have undetectable baseline TSH levels but still show a normal TSH response to a large pharmacological dose of TRF as we showed previously (Otsuki et al., 1972, 1973b). Hence TRF test with a small dose, such as $50-100 \mu \mathrm{g}$, can be a sensitive test of impaired TSH reserve and can make a difference between pituitary diseases and hypothalamic lesions.
Although we used a small dose of TRF, half of the patients with pituitary chromophobe adenoma responded normally. The results showed that the pituitary had a great TSH reserve and that its destruction was not "all or none".

In acromegaly, TSH reserve was almost normal; 5 of 6 showed a normal response. Hall et al. (1972) reported that TSH reserve was often impaired in acromegalics. This difference may be due to treatment. None of our patients had been treated. Effective treatment of acromegaly may be accompanied by impaired TSH reserve (Hall et al., 1972).

In patients with hypothalamic lesions without major pituitary lesions, a normal TSH response to TRF in 15 patients and a supernormal response in 6 were observed. Moreover, 17 of 21 showed the delayed pattern of TSH response. Although six patients with supernormal TSH response and 5 with normal response had clinical and biochemical evidence of hypothyroidism, as shown in Table 5, baseline plasma TSH levels were low, thyroid autoantibody was negative and responded normally to exogenous TSH. From these results, the existence of both hypothalamic lesions and primary hypothyroidism in the same subjects could be denied. Hence the hypothyroidism observed in these patients was due to lack of effective endogenous TRF secretion. These patients with hypothalamic lesions had a normal TSH concentration in the pituitary gland in spite of the deficiency of endogenous TRF (D'Angelo, 1958; Martin et al., 1970), which resulted in a supernormal TSH response induced by a small dose of exogenous TRF. From these findings it seems to be possible to postulate for the criteria of hypothalamic (tertiary) hypothyroidism: i) the existence of clinical and biochemical evidence of hypothyroidism, ii) with normal thyroid gland, which can respond to exogenous TSH normally and iii) with normal pituitary TSH reserve, in other words, normal or supernormal TSH response to a "small" dose of TRF, such as $50 \mu \mathrm{g}$. 
Of the seven patients who were diagnosed as diabetes insipidus clinically, 2 showed a normal response and 4 had a supernormal response. Moreover, 6 of the seven patients showed a delayed rise of TSH. This pattern of TSH response was just the same as that seen in the patients with determined hypothalamic lesions. According to the pattern of TSH response, diabetes insipidus observed in this study was probably induced by hypothalamic lesions. However the effect of ADH deficiency on TSH response to TRF should be considered before coming to decision.

We described the usefulness of TRF test with a small dose as a sensitive test for pituitary TSH reserve. The delayed pattern of TSH response and normal or supernormal response to such a small dose of TRF indicate the presence of hypothalamic lesions and can differenciate them from patients with pituitary diseases who showed an absent or a subnormal response. However, the delayed pattern of TSH response was also found in 8 of 21 with pituitary chromophobe adenoma. 7 of 8 who showed the delayed pattern of response had been subjected to local treatment, whereas only one with untreated pituitary disease had a delayed response. This difference may indicate hypothalamic dysfunction or vascular damage resulting from the local treatment.

\section{References}

Bowers, C. Y., A. V. Schally, D. S. Schalch, C. Gual, A. J. Kastin and K. Folkers (1970). Biochem. Biophys. Res. Comm. 39, 352.

Bowers, C. Y., A. V. Schally, G. A. Reynolds, and W. D. Hawley (1967). Endocrinology 81, 741 .

Burgus, R., T. F. Dunn, D. Desiderio, and R. Guillemin (1969), C. R. Acad. Sci. (Paris) 269, 1870.

D'Angelo, S. A. (1958). J. Endocrinol. 17, 286.

DeMoor, P., O. Steeno, M. Raskin, and A. Hendrikx (1960). Acta Endocrinol. (Kbh) 33, 297.

Fleischer, N., R. Burgus, W. Vale, T. F. Dunn, and R. Guillemin (1970). J. Clin. Endocrinol. 31, 109.

Folkers, K., F. Enzmann, J. Bller, C. Y. Bowers, and A. V. Schally (1969). Biochem. Biophys. Res. Comm. 37, 123.

Gillessen, D., A. M. Felix, W. Largier, and R. O. Studer (1970). Helv. Chim. Acta 53, 63.

Grant, G., W. Vale, and R. Guillemin (1972). IV International Congress of Endocrinology (Abstracts) 84.

Hall, R., J. Amos, R. Garry, and R. L. Buxton (1970). Brit. Med. J. 2, 274.

Hall, R., B. J. Ormston, G. M. Besser, and R. J. Cryer (1972). Lancet 1, 759.

Hershman, J. M., and J. A. Pittman, Jr. (1970). J. Clin. Endocrinol. 31, 457.

Karlberg, R., S. Almquit, and S. Werner (1971). Acta Endocrinol. (Kbh.) 67, 288.

Martin, J. B., R. Boshans, and S. Reichlin (1970). Endocrinology 87, 1032.

Mittler, J. C., T. W. Redding, and A. V. Schally (1969). Proc. Soc. Exp. Biol. Med. 130, 406.

Ormston, B. J., R. Garry, R. J. Cryer, and G. M. Besser (1971). Lancet 2, 10.

Otsuki, M. (1971). Folia Endocrinol. Japon. 47, 301 (In Japanese).

Otsuki, M., M. Sakoda, and S. Baba (1972). Kobe J. Med. Sci. 18, 215.

Otsuki, M., and S. Baba (1973a). J. Clin. Endocrinol. 36, 95.

Otsuki, M., H. Mori, S. Baba, and N. Hiroshige (1973b). Acta Endocrinol. (Kbh.) (in press)

Saito, S., K. Abe, H. Yoshida, T. Kaneko, E. Nakamura, N. Shimizu, and N. Yanaihara (1971). Endocrinol. Japon. 18, 101.

Sakoda, M., M. Otsuki, N. Hiroshige, K. Kanao, A. Yagi, and M. Honda (1970). Ibid. 17, 541.

Schalch, D. S., and M. L. Parker (1964). Nature 203, 1142.

Wilber, J. F. (1971). Endocrinology 89, 873.

Wilber, J. F., and M. J. Seibel (1972). IV International Congress of Endocrinology (Abstracts) 85 . 